Часопис из области економије, меначмента и информатике

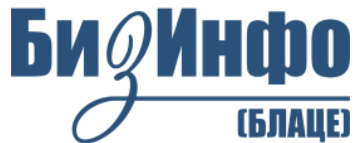

Година 2019, волумен 10, број 2, стр. 95-109

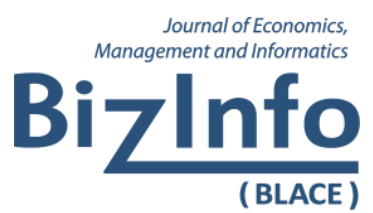

Year 2019, Volume 10, Number 2, pp. 95-109

\author{
Прегледни рад/ Review paper \\ УДК/UDC: 005.32:331.101.3-055.2(594) \\ 005.336.5:004
}

doi:10.5937/bizinfo1902095S

\title{
WHY DO (NOT) WOMAN ENTREPRENEURS JUMP INTO TECHNOLOGY BASED BUSINESS?
}

\author{
Dahli Suhaeli \\ Muhammadiyah University of Magelang, Magelang, Java, Indonesia \\ Nia Kurniati Bachtiar ${ }^{1}$ \\ Muhammadiyah University of Magelang, Magelang, Java, Indonesia
}

\begin{abstract}
This paper investigated reasons behind the lack of woman entrepreneurs contribution in starting technology based business in Indonesia and what assistance needed to increase its number. Our major goal was to maximize the advantages of technology in business especially to woman owned business by setting a framework to simplify them to enter this sector. The basic idea of this paper was to increase number of woman entrepreneurs in technology based business in Indonesia by answering the research questions and setting a extended framework from Technology Acceptance Model (TAM) to be suited for woman entrepreneurs.

Keywords: Woman Entrepreneurs, TAM, Technology Based business, Startup Business, Internet
\end{abstract}

\section{INTRODUCTION}

The utilization of technology in all industries is unavoidable. Since internet of things dominat the way of business, entrepreneurs are forced to be able to implement technology to their businesses. Data from 2017. indicated 53\% business of both Large Organizations (LOs) and Small and Medium Enterprises (SMEs) have already depended their activities in technology and the usage of internet network (Insight, 2017) and this number is still enhancing. The most update data in 2018 indicated that more than two third businesses in the world are exploiting technology and internet tools in their

${ }^{1}$ niakurniatibachtiar@ummgl.ac.id 
daily activities (Genome, 2018). Accordingly, number of technology based companies increases significantly during past years. This claim is proven by the data shown that technology based business especially technology based startup has escalated in recent years (Hudson, 2015; Statista, 2017; GEM, 2017. On the other hand, Jovkic et al (2018) underlined that high extend of technology development can be used to gain better market position and it is applied for all type of business. (Jovkić, Urošević and Vuković, 2017).

However, reality shows that the number of entrepreneurs in this field is uneven between men and women where this field is still men dominated until now (Tambunan, 2009; Hampton, Cooper and McGowan, 2009; Mitchelmore, Rowley, 2013). It is quite unfortunate because women entrepreneurs have a significant potency both in their number and their capability to success. At the same time, during this 4.0 era, businesses need to maximize technology and internet in order to grow and sustain.

That significant gap drives authors to discuss the reality happened in entrepreneurship world and formulate the following research questions: (1) Why women tend to avoid starting a technology based business? and (2) What assistance need to increase the number of women entrepreneurs in technology based business?. Subsequently, the aims of this research are: (1) discovering the reasons behind uneven numbers between men and women whose start a technology based business, (2) identificating constraints faced by women entrepreneurs in establishing technology-based business, and finally (3) delivering a proposed/extended model to resolve the problems. The novelties of this research referring (1) defining the constraints encountered by women entrepreneurs in starting technology based business specifically from internal reason and (2) providing an extended model to assist women entrepreneurs in establishing this type of business.

\section{LITERATURE REVIEW}

As previously described technology is applied in every layer of our life, so does in business. The shifting from conventional business to digital or technology-based business is a must for all organizations despite of their size and products/services they offer. This part will discuss some important points regarding the issue. Firstly, it will provide the previous literatures relate to the study. Secondly, technology based business will be explained to give definition and boundaries. Privileges technology offered to the business, the potency of women entrepreneurs, Technology Acceptance Model (TAM) in shifting from conventional to technology-based business will become the next discussion. 


\subsection{THEORITICAL PERSPECTIVES}

The important of technology usage in business drives researchers to conduct research in this field. Some previous literatures recorded almost the same findings about the significant effect of technology in both Large Organizations (LOs) and Small and Medium Enterprises (SMEs). Here are some of them:

Table 1. Literature review

\begin{tabular}{|c|c|c|}
\hline Authors & Title & Findings \\
\hline $\begin{array}{l}\text { (Levebvre, Mason, } \\
\text { 1997). }\end{array}$ & $\begin{array}{l}\text { The influence of prism in } \\
\text { SMEs: the power of CEO's } \\
\text { perceptions on technology } \\
\text { policy and its } \\
\text { organizational impacts }\end{array}$ & $\begin{array}{l}\text { A more aggressive technology policy } \\
\text { leads to greater realized innovation } \\
\text { efforts, which in turn are positively } \\
\text { related to export performance and } \\
\text { financial performance }\end{array}$ \\
\hline $\begin{array}{l}\text { (Hampton, Cooper } \\
\text { and McGowan, } \\
\text { 2009) }\end{array}$ & $\begin{array}{l}\text { Female Entrepreneurial } \\
\text { Networks and Networking } \\
\text { Activity in Technology- } \\
\text { based Ventures }\end{array}$ & $\begin{array}{l}\text { Greater profiling in media of successful } \\
\text { female entrepreneurs is urgently needed } \\
\text { to encourage more women to engage in } \\
\text { technology-based venturing }\end{array}$ \\
\hline $\begin{array}{l}\text { (Petti, Zhang, } \\
\text { 2011) }\end{array}$ & \begin{tabular}{l}
\multicolumn{1}{c}{ Factors influencing } \\
technological \\
entrepreneurship \\
capabilities: Towards an \\
integrated \\
framework for Chinese \\
enterprises
\end{tabular} & $\begin{array}{l}\text { Overview of the factors that affect } \\
\text { technological entrepreneurship } \\
\text { capabilities, with particular reference to } \\
\text { Chinese enterprises }\end{array}$ \\
\hline (Han, Park, 2017) & $\begin{array}{l}\text { Case study on adoption of } \\
\text { new technology for } \\
\text { innovation: Perspective of } \\
\text { institutional and corporate } \\
\text { entrepreneurship }\end{array}$ & $\begin{array}{l}\text { Kumho Tire (their research object) } \\
\text { takes great satisfaction in lots of } \\
\text { failures to develop the cutting edge } \\
\text { technology using advanced information } \\
\text { and communication technology } \\
\text { cultivated by heterogeneous institution } \\
\text { and corporate entrepreneurship }\end{array}$ \\
\hline $\begin{array}{l}\text { (Bruquea, } \\
\text { Moyano, 2017) }\end{array}$ & $\begin{array}{l}\text { Organizational } \\
\text { determinants of information } \\
\text { technology adoption and } \\
\text { implementation in SMEs: } \\
\text { The case of family and } \\
\text { cooperative firm }\end{array}$ & $\begin{array}{l}\text { There are a number of internal factors } \\
\text { that influence the success of the } \\
\text { adoption decision, on the one hand, and } \\
\text { the implementation process of } \\
\text { technology adoption }\end{array}$ \\
\hline
\end{tabular}

Above findings indicated that technology is able to direct business to their improvement and without using it, businesses will most likely face their declining process. However, above researches focused in technology usage in general, the role and intention of the LOs and SMEs owner. The literatures also focused to entrepreneurs whom responsible to the business activity and resulted that technology-based business were dominated by men. Among all above researches only one of them specifically discussed about role of 
women entrepreneurs in technology-based business. As previously mentioned, technology-based businesses were male dominated Hence, it is challenging to find women in that particular business.

\subsection{TECHNOLOGY BASED BUSINESS}

Technology-based business as defined in this research are combination taken from several sources and form it into: the business that maximize the knowledge of technology and science in its daily activity. Not only by using technology in their production, research and development and mostly its marketing strategy by using market oriented technological innovation. On the other hand, technology based business is a business that integrate all form of technology directly to the business operation (OVTT, 2010; Garcia, 2013). For this research, the scope of technology based business will be limited to technology based startups. Startup based on Global Entrepreneurship Development Index $(G E D I)$ is defined as a new established business that has a goal to be a global business. It differs from Small Medium Enterprises (SMEs) which operate locally (GEDI, 2017).

Levebrve and Mason claimed that technology enlarged the competition among business in particular industry (Levebrve, Mason, 1997). By using technology, business both big and small are able to open up to compete with other businesses whom are not their competitor before. Following to that, technology also drives innovation within organization or business. Technology is able to create incremental, disrupted and radical innovation that can completely change the "face" of the business (Kennard, 2017). Innovation resulted from technology implementation within the business will construct a better organizational performance for enhancing the competitive advantage of a business.

\subsection{TECHNOLOGY ACCEPTANCE MODEL (TAM)}

Research about TAM has been conducted since 1989 where the first model of TAM introduced by Fred Davis (Gordon, 2013). This model has been extended and differentiated according to the scientific field. The conceptual model was released in 1985 (Marangunic and Granic, 2015) before it stated in 1989 by the same person - Fred Davis. The model modified in 1996 by Venkatesh and Davis then by the same authors, it extended to the more complex and more in-depth in 2000 which resulted TAM2 (Holden, Karsh, 2010; Marangunic and Granic, 2015; Gordon, 2013; Lai, 2017).

TAM is basically a model to explain and explore how was technology accepted, implemented? and what factors drives people to use technology. TAM defines the stimulus and people behavior. Thus, this model is the basic 
conceptual in making Theory of Planned Behavior $(T P B)$ and Theory of Reasoned Action (TRA). Below are the development of TAM:

Figure 1. Conceptual Model

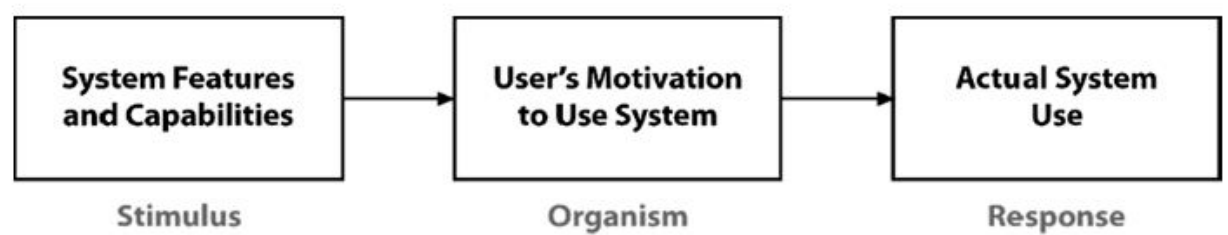

Source: Marangunic', N., \& Granic, A. (2015). Technology acceptance model: a literature review from 1986 to 2013 Nikola. Univ Access Inf Soc, 14, 81-95.

Figure 2. The first Technology Acceptance Model

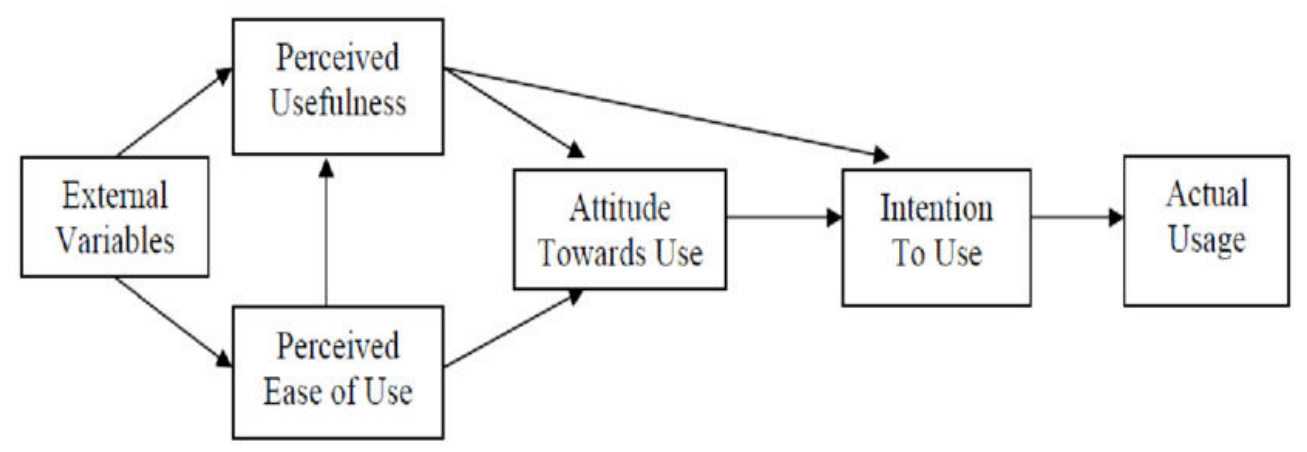

Source: Davis, F. D. 1989. Perceived usefulness, perceived ease of use, and user acceptance of information technology. MIS quarterly, 319-340.

Figure 3. The extension of Technology Acceptance Model

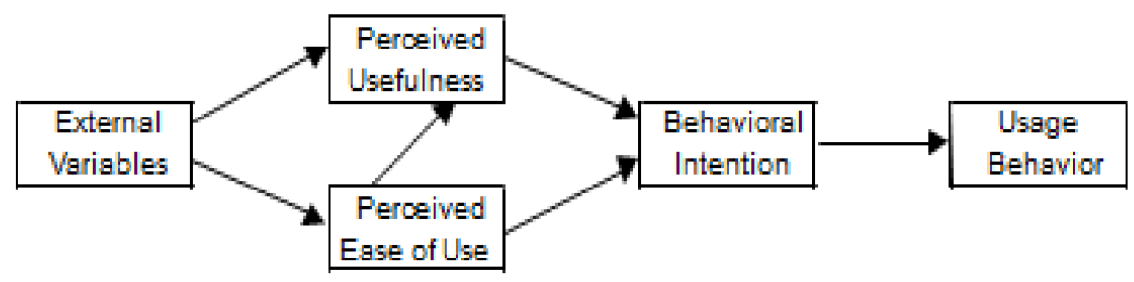

Source: Venkatesh, V. and Davis, F. D. 1996. A model of the antecedents of perceived ease of use: Development and test. Decision sciences, 27(3), pp.451-481. 
Figure 4.The extension of Technology Acceptance Model 2

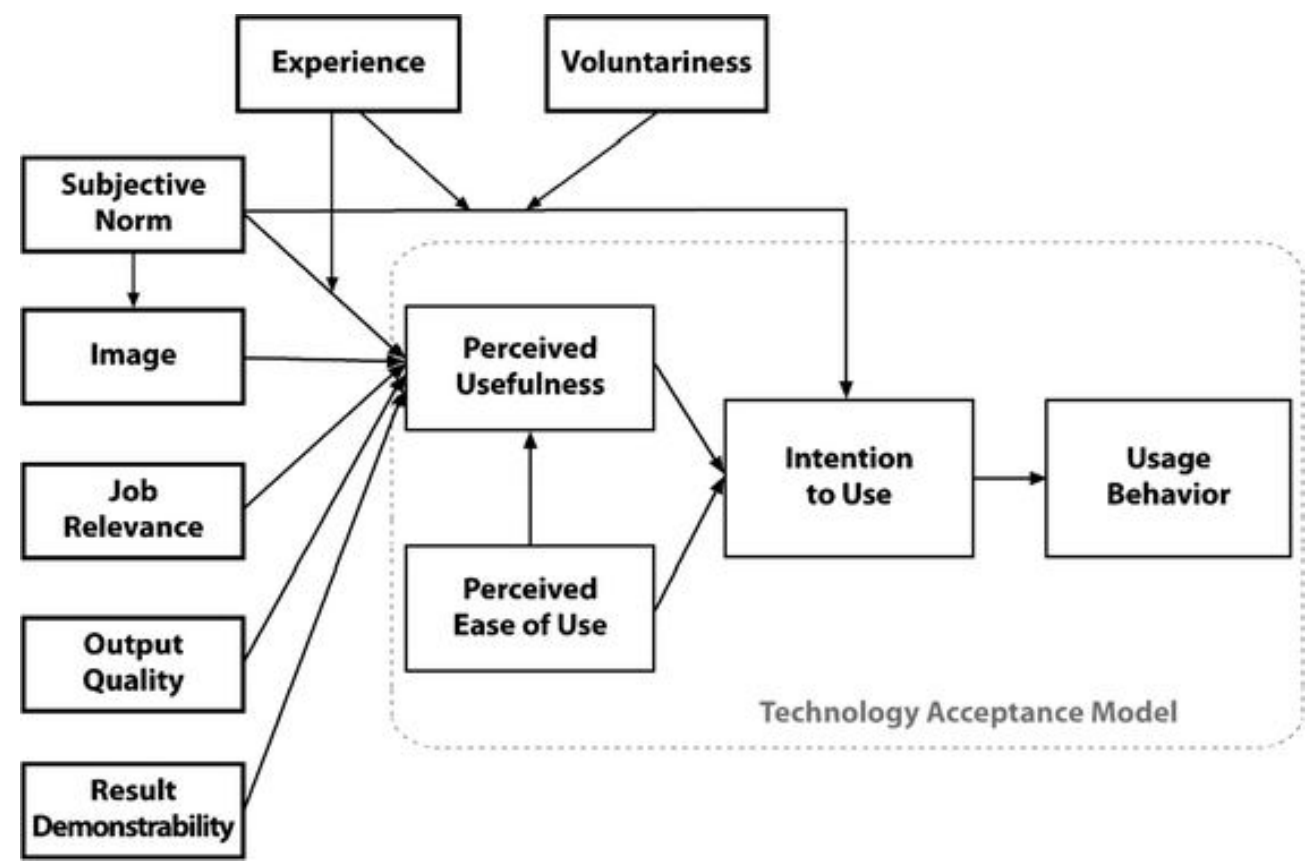

Source: Venkatesh, V. and Davis, F. D. 2000. A theoretical extension of the technology acceptance model: Four longitudinal field studies. Management science, 46(2), pp.186-204.

However, among all, there is not any specific model that can be implemented in business especially to women entrepreneurs. Hence, this study will build an extended model that fit to business condition. specifically for women entrepreneurs, in technology-based companies.

\subsection{THE MAXIMIZATION OF TECHNOLOGY IN BUSINESS}

The question arises: is the technology utilization only influence behavior and creating stimulus? The answer is NO, at least in business field. Apart of above reasons, technology is employed in the new marketing mix, the modern supply chain of a product and service, the value chain and the competition strategy.

In marketing itself, technology has been utilized and modified to be applied in modern marketing that also known as digital marketing (Krstic and Krstic, 2015). Literature recorded 7 methods used in digital marketing which fully employed technology in its practice. Below are the methods: 
Figure 5. Digital Marketing Strategy

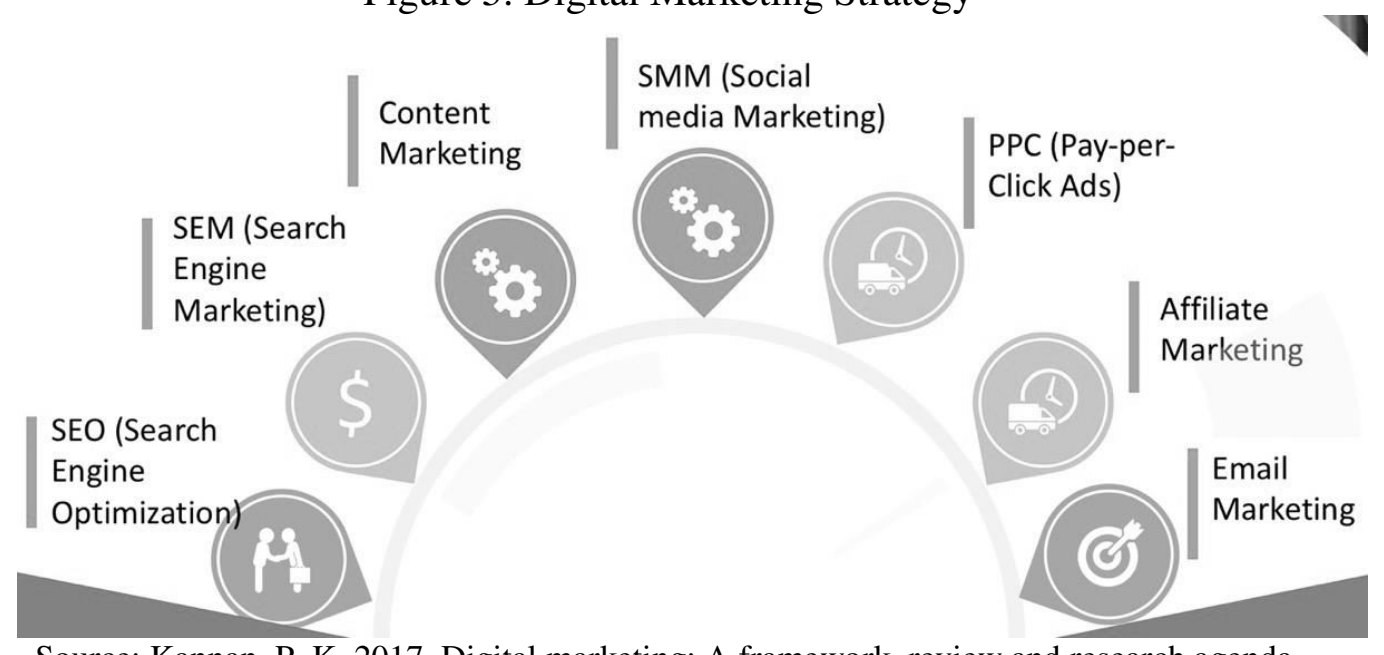

Source: Kannan, P. K. 2017. Digital marketing: A framework, review and research agenda. International Journal of Research in Marketing, 34(1), pp.22-45.

\subsection{THE POTENCY OF WOMEN ENTREPRENEURS}

World bank in 2018 recorded that women population in the world reached 49.6\% (Bank, 2018). It means that the potency between men and women in generating a business are slightly equals. Thus, the number of entrepreneurs should not be too different by gender. In Indonesia, percentage of women entrepreneurs also significantly increase even though it is not as high as the number of men entrepreneurs. Among 260 million people in Indonesia in 2017, 58,97 million are entrepreneurs. Nevertheless, only 14,3 million out of 58,97 million are women entrepreneurs. Even though the number is still a forth of total entrepreneurs in Indonesia, the total has gradually increased from 12,7 million in the previous year (Kontan, 2017)

The potency of women entrepreneurs also recorded in various countries in the world. Africa is a continent that have the highest women entrepreneurs. Other data stated that developing countries have more women entrepreneurs than men entrepreneurs while men entrepreneurs dominated in developed countries (Hatcher, Terjesen and Planck, 2007; Forje, 2009). With the enhancing number of women entrepreneurs and their role in various businesses, can be stated that the potency of women entrepreneurs especially in technology based business can still be improved.

\section{RESEARCH METHOD}

Case study research is included as one of choices in research strategy apart of experiment, written survey, document analysis and historical study 
(Teegavarapu, Summers and Mocko, 2008). The advantage of case study research is its ability in conducting contemporary event when the one need to be analyzed is the contextual event. It is strengthen Eisenhardt that mentioned case study research as an empirical study that can be applied in quantitative and qualitative approach (Eisenhardt, 1989). Following to that, Yin added that case study research should assist in constructing theories, accommodate indirect observation and assist in revealing generalization. Hence, this approach is able to "contribute in defining the problem and building theories" (Yin, 2003). In this study, population represents set of 54 startups that registered in Indonesia 2018 (Bekraf, 2018). From this population, only $8.82 \%$ or 5 startups are owned by woman. Thus, the sample of this research are those 5 startups. Based on the number, it is straightly clear that women participation in this era in limited. So far, In general, women entrepreneurs in Indonesia run a conventional business that mostly focus to Food and Beverage (F\&B) or culinary industry (Tambunan, 2009; K3PA, 2016; GEDI, 2017; Hafner and Krstić, 2011).

\section{DISCUSSION AND FINDINGS}

\subsection{TOWARDS THE CREATION OF TECHNOLOGY BASED BUSINESS}

Technology is a significant element nowadays, both for business and customers. The exploitation of technology in business can lead to a substantial improvement and strong presence in the industry. However, it also carries challenges and issues. This part will elicit the findings of the research and answering the research questions.

First, entrepreneurial character is mainly essential to business owner/founder. Interview conducted in this research discovered that there are some major characteristics that mainly important for the owner/founder. Those characteristics include focus, highly determined, firm, patient, highly commitment, creative and extrovert (McClelland, 1987; Kwun \& Jeong, 2012). It is substantial for entrepreneurs to have those characteristics in order to develop their business. The good news is those characteristics can be built, hence, someone who does not fit above characteristics still have opportunity to be an entrepreneurs. As mentioned by interviewees:

"I wasn't extrovert before, this job is shaped the way I am now. Indeed, your entrepreneurial character can be built over time" Interviewee 1

"Women are afraid to jump into this sector due to our basic character that likely to stay in our comfort zone. But, we can change, our character can be shaped especially when we focus as entrepreneur" Interviewee 2,3 
"I do agree that we can change. I'm a different person since I jump into this business but I change in a good way" Interviewee 4

"Sometimes I'm hesitate in doing something unfamiliar but recently I don't have any problem at all. Yes, our entrepreneurial character can be built" Interviewee 5

This finding supports Littunen that underlined that entrepreneurial practice increased ones mastery in certain character, the main point need to be remembered is the individual willingness to change from unsuitable character to suitable character (Littunen, 2000).

Second, knowledge, stamina and entrepreneurs mentality come after entrepreneurs characteristic. There is a huge difference between starting a business in order to survive and starting it because they choose to do it. When someone chooses entrepreneurship as their way of life, he/she will ensure the business is profitable and well performed. In order to do so, entrepreneurs will always fill themselves with various knowledge needed. As well as the stamina and mentality, being an entrepreneur requires strong stamina and mentality. Working as entrepreneurs means that someone needs to be ready $24 / 7$ without any specific working hour. For entrepreneurs, every hour is working hour. On the other hand, entrepreneurs must be patient because they will encounter many failures in running their business either failure in strategy, financial and growth. Thus, the need of strong mentality to not giving up is important for entrepreneurs as stated by interviewees:

"This is exhausting because we don't have specific working hours but strangely I enjoy it very much" Interviewee 1,3,4,5

"I sometimes feel so tired and difficult to manage my time between working and family. But, I agree since I love my job, I push myself to do well in both" Interviewee 2

Third, technology based business indeed is a male dominated industry. The interview conducted confirms that male presence in this industry is strongly unavoidable. With literatures confirm the same thing as well. However, the interview revealed that there is psychologist effect comes with it. Apparently, most women feel uncomfortable surrounded with men who they do not know well. Following to that, interviewee emphasized that:

"We don't feel too comfortable to communicate with opposite gender specifically when we don't know them before. It is a huge problem because this industry surrounded by male which will be difficult to avoid this kind of relationship, especially when we want to discuss, sharing knowledge and learn. This become one obstacle why women avoid this industry" All interviewees. 
This finding is confirmed by research by Bruni that there is multidimensional problem occur in men and women relationship especially in business (Bruni, Gherardi and Poggio, 2004).

Forth, lack of capital = slow growth speed. Capital i.e money is recognizable as the main obstacle of business growth mostly for small business. Lack of finding may cause the slowdown in business growth and in the same time can threaten the business sustainability. This challenge will need to be encountered by all entrepreneurs and women entrepreneurs is no exception. Following to that, interviewee also revealed that there is not any specific funding given to startup business from Indonesian government. Until now, the funding such us: soft loan or government grant only given for SMEs but not specifically to startup business as underlined by interviewee:

"There isn't any specific funding scheme for startup business. Hence, we don't have any suitable loan that fit our business" Interviewee 1,5

"Capital is always be a major problem for all businesses. We are surely included. Lack of money make my business experience slow growth" Interviewee 2,3,4

This finding strengthens early literatures by Salavou and McAdam (Salavou, 2004; McAdam, 2004).

\subsection{TOWARDS THE ENTRANCE MODEL TO TECHNOLOGY BASED BUSINESS}

Looking at the important of women entrepreneurs presence in technology based business, it is substantial to assist them in the entrance model. Thus, the last finding of this study will focus to that point

Fifth, proposed model for women entrepreneurs. This study argues that to be able to participate in technology based business, TAM is not enough to be an assistance model. To start a technology based business, women entrepreneurs need a specific framework to guide them. Hence, this research will provide a proposed model to assist the entrance and the role of women entrepreneurs in technology based business. The proposed model as follow: 
Figure 6. Proposed Entrance Model

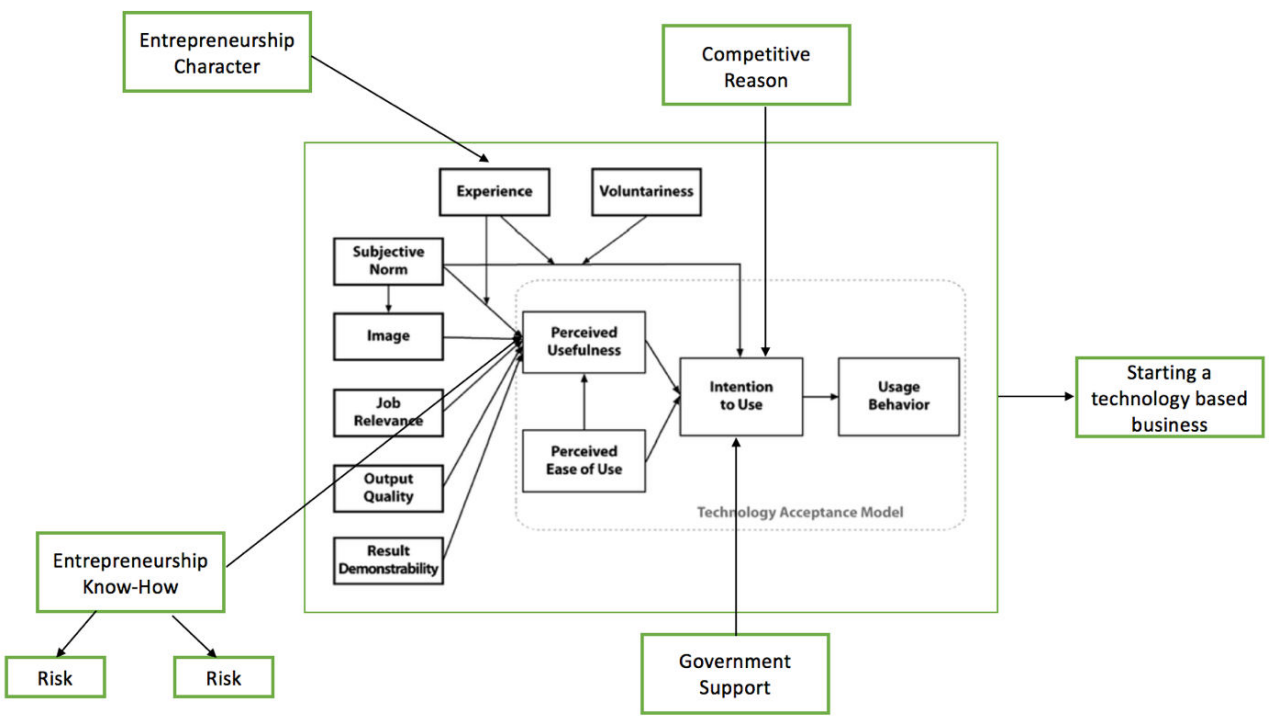

Source: Authors

The model above explains that apart of TAM, there are some elements that are crucial to women entrepreneurs' entrance model to technology based business. Women have to build their entrepreneur characters first to be able to pursue entrepreneurship knowledge or know-how especially about the risk and opportunity in entrepreneurial world. On the other hand, women and also all entrepreneurs cannot stand alone in starting a business, government support is a major element need in assisting entrepreneurs. Lastly, women have to understand that entering technological based business is due to competitive reason before their business decline, and "killed" by other business. Hence, the proposed model as described above.

\section{CONCLUSSION}

We cannot avoid technology exploitation in business nowadays, specially due to the development of industrial revolution 4.0 where technology is used in every layer of human activity. For entrepreneurs, technology implementation in their business will give them huge advantages due to the easiness, flexibility and its ability to grab more market. However, this advantage has not been fully adapted by women entrepreneurs. In fact, in Indonesia, the number of women entrepreneurs are enhancing through years and reach almost a half from the total of entrepreneurs in country. Thus, avoiding technology based business will be a great loss to women entrepreneurs. On the other hand, there is a need to create an assisting model to guide women entrepreneurs to enter or start a technology based business. Hence, this study 
proposes an entrance model to technology based business as a development model of TAM.

However, this study is limited to 1 (one) city in Indonesia, while it has strong internal validation because it is taken all population of woman-owned startup business, it has less strong external validation. For future study, it is suggested to take sample in different cities to finally able to test the external validation for the result.

\section{REFERENCES}

1. Benouali, J., Clodic, D., Mola, S., Presti, G. L., Magini, M., Malvicino, C. and Fiat, C. R., 2003. Fuel consumption of Mobile air conditioning-Method of testing and results. In The Earth Technology Forum (pp. 1-10).

2. The World Bank, 2018. World Bank Open Data. [online] Available at: <https://data.worldbank.org/indicator/SP.POP.TOTL.FE.ZS> [Accessed 12 November 2018].

3. Bekraf, 2018. Mapping \& Database Startup Indonesia 2018. [pdf] Available at: <https://www.bekraf.go.id/pustaka/page/mappingdatabase-startup-indonesia-2018> [Accessed 12 November 2018].

4. Bruni, A., Gherardi, S. and Poggio, B. 2004., Entrepreneur-mentality, gender and the study of women entrepreneurs. Journal of Organizational Change Management, 17(3), pp.256 - 268.

5. Bruquea, S. and Moyano, J. 2017., Organisational determinants of information technology adoption and implementation in SMEs: The case of family and cooperative firm. Technovation, 27(5), 241-253.

6. Dahnil, M. I., Marzuki, K. M., Langgat, J. and Fabeil, N. F., 2014. Factors Influencing SMEs Adoption of Social Media Marketing Mohd. Social and Behavioral Sciences, 148, pp.119 - 126.

7. Davis, F. D., 1989. Perceived usefulness, perceived ease of use, and user acceptance of information technology. MIS quarterly, 13(3), 319340.

8. Eisenhardt, K., 1989. Building Theories from Case Study Research. The Academy of Management Review, 532-550.

9. ETSAP, 2010. April. Automotive LPG and Natural Gas Engines. Technology Brief T03.

10. Forje, L. C., 2009. A Historical Development of Entrepreneurship in the Cameroon Economy from 1960-2007. Journal of Asia Entrepreneurship and Sustainability, 5(9), pp.1-16.

11. Garcia, J., 2013. Passion for startup. [online] Available at: <https://passionforstartups.com> [Accessed 14 November 2018]. 
12. GEDI, 2017. The Global Entrepreneurship Index. [pdf] Available at: $<$ https://thegedi.org/wp-content/uploads/dlm_uploads/2017/11/GEI2018-1.pdf> [Accessed 2 April 2019].

13. GEM, 2017. Global Entrepreneurship Index 2017. Washington: GEDI.

14. Genome, S., 2018. Global StartUp Ecosystem Report 2018. Startup Genome.

15. Gordon, D. 2013. Technology Acceptance Model. [online] Available at: $\quad$ https://www.slideshare.net/DamianGordon1/technologyacceptance-model $>$ [Accessed 13 November 2018].

16. Hafner, P. and Krstić, M., 2011. Theory of Rational Choice in the Analysis of Criminal Behavior. Ekonomika, 57(1), pp.37-47.

17. Hampton, A., Cooper, S. and McGowan, P., 2009. Female Entrepreenurial Networks and Networking Activity in Technologybased Ventures. International Small Business Journal, 27(2), 193-214

18. Han, J. and Park, C. M., 2017. Case study on adoption of new technology for innovation: Perspective of institutional and corporate entrepreneurship. Asia Pacific Journal of Innovation and Entrepreneurship, 11(2), pp.144-158.

19. Hatcher, C., Terjesen, S. and Planck, M., 2007. Towards a New Theory of Entrepreneurship in Culture and Gender: a Grounded Study of Thailand's most Successful Female Entrepreneurs. Brisbane: AGSE 2007.

20. Hofmann, F., 2011. Converting Vehicles to Propane Autogas Part 1: Installing Fuel Tanks and Fuel Lines. Washington D.C: Propane Education \& Research Council.

21. Holden, R. J. and Karsh, B. T., 2010. The technology acceptance model: its past and its future in health care. Journal of biomedical informatics, 43(1), pp.159-172.

22. Hudson, M., 2015. New Report Confirms Startup Activity Increasing After Years Of Decline. [online] Available at: $<$ https://www.forbes.com/sites/mariannehudson/2015/06/22/new-reportconfirms-startup-activity-increasing-after-years-of-decline/> [Accessed 6 March 2019].

23. Insight, 2017. These Small Business Technology Statistics Are Surprising. [online] Available at: <https://www.insight.com/en_US/content-and-resources/2017/02232017these-small-business-technology-statistics-are-surprising.html> [Accessed 21 Novembar 2018].

24. Jovkić, J., Urošević, S. and Vuković, M., 2017. Influence and importance of company activities to achieving more favorable market position of SMBs by managing intelectual capital. Bizinfo (Blace), 8(1), pp.1-16. 
25. Kannan, P. K., 2017. Digital marketing: A framework, review and research agenda. International Journal of Research in Marketing, 34(1), pp.22-45.

26. K3PA, 2016. Statistik Gender Tematik - Potret Ketimpangan Gender Dalam Ekonomi. Jakarta: Kementerian Pemberdayaan Perempuan dan Perlindungan Anak.

27. Kennard, M., 2017. Innovation Management. Birmingham: UoB.

28. Kontan, 2017. Jumlah pelaku UMKM di 2018 diprediksi mencapai 58,97 juta orang [online] Available at: $<$ https://keuangan.kontan.co.id/news/jumlah-pelaku-umkm-di-2018diprediksi-mencapai-5897-juta-orang> [Accessed 26 Novembar 2018].

29. Krstić, B. and Krstić, M., 2015. Models of Irrational Behaviour of Household and Firm. Ekonomika, 61(4), pp.1-10.

30. Kwun, M. Y. and Jeong, H. J. 2012., The effect of entrepreneurs' characteristic, technological capabilities and network on firm performance of technology-based start-ups. Asia-Pacific Journal of Business Venturing and Entrepreneurship, 7(1), pp.7-18.

31. Lai, P., 2017. The Literature Review of Technology Adoption Models and Theories for the Novelty Technology. Journal of Information Systems and Technology Management, 14(1), pp.21-38.

32. Levebvre, L. and Mason, R. L., 1997. The Influence of Prism in SMEs: The Power of CEOs Peception on Technology Policy and Its Organisational Impacts. Management Science, 43(6), pp.856-878.

33. Littunen, H., 2000. Entrepreneurship and the characteristics of the entrepreneurial personality . International Journal of Entrepreneurial Behavior \& Research, pp.295-310.

34. Marangunic, N. and Granic, A. 2015. Technology acceptance model: a literature review from 1986 to 2013 Nikola. Univ Access Inf Soc, 14, pp.81-95.

35. McAdam, R., McConvery, T. And Armstrong, G., 2004. Barriers to innovation within small firms in a peripheral location. International Journal of Entrepreneurial Behavior \& Research, 10(3), pp.206-221.

36. McClelland, D., 1987. Characteristics of Successful Entrepreneurs. The Journal of Creative Behaviour, 21(3), pp.219-233.

37. Mitchelmore, S. and Rowley, J., 2013. Entrepreneurial competencies of women entrepreneurs pursuing business growth. Journal of Small Business and Enterprise Development, 20(1), 125-142.

38. OVTT, 2010. Technology based companies. [online] Available at: <https://en.ovtt.org/technology_based_companies> [Accessed 20 Novembar 2018].

39. Pasco, 2006. Latent Heat of Vaporization. In Physics with the Xplorer GLX (p.229). 
40. Petti, C. and Zhang, S., 2011. Factors influencing technological entrepreneurship capabilities: Towards an integrated research framework for Chinese enterprises. Journal of Technology Management in China, 6(1), pp.7-25.

41. Salavou, H., Baltas, G. and Lioukas, S., 2004. Organisational innovation in SMEs: the importance of strategic orientation and competitive structure. European journal of marketing, 38(9/10), pp.1091-1112.

42. Setiyo, M., 2013. Desain Coupling dan Mixer Variabel untuk Mempercepat Pemanfaatan LPG Sebagai Bahan Bakar Angkutan Umum Serta Pemilihan Vaporizer Yang Sesuai. In d. Ahmad Dading Gunadi, Direktori Hasil Insentif Riset Sistem Inovasi Nasional (Sinas) (p. 160). Jakarta: Asdep Relevansi Program Riptek, Deputi Bidang Relevansi dan Produktivitas Iptek, Kementerian Riset dan Teknologi.

43. Startups, 2017. Everyone Pivots: The Truth About A Startup Pivot. [online] Available at: <https://www.startups.com/library/expertadvice/startup-business-pivot> [Accessed 10 March 2019].

44. Statista, 2017. Global startups - Statistics \& Facts. [online] Available at: <https://www.statista.com/topics/4733/startups-worldwide/> [Accessed 6 March 2019].

45. Tambunan, T., 2009. Women entrepreneurship in Asian developing countries: Their development and main constraints. Journal of Development and Agricultural Economics, 1(2), pp.27-40.

46. Teegavarapu, S., Summers, J. and Mocko, G., 2008. Case Study Method for Design Research: A Justification. Proceedings of the ASME Design Engineering Technical Conference.

47. Venkatesh, V. and Davis, F. D., 2000. A theoretical extension of the technology acceptance model: Four longitudinal field studies. Management science, 46(2), pp.186-204.

48. Venkatesh, V. and Davis, F. D., 1996. A model of the antecedents of perceived ease of use: Development and test. Decision sciences, 27(3), pp.451-481.

49. Werpy, M. R., 2010. Propane vehicle: Status, Challenges, and Opportunities. Chicahgo: Center for Transportation Research, Argonne National Laboratory.

50. WLPGA, 2012. Autogas Incentive Policies. Neuilly-sur-Seine: World Liquified Petroleum Gas Association.

51. Yin, R., 2003. Case study research: Design and Methods, Sage Publications.

Received: 11 November, 2019

Accepted: 3 December, 2019 
